\title{
ADVERSE POSSESSION AND UNINCORPORATED ASSOCIATIONS
}

\section{Dr Alan Dowling, Senior Lecturer in Law, Queen's University Belfast}

It is trite law that an unincorporated association has no separate persona from those of its members, save for the purposes of taxation. ${ }^{1}$ This causes well recognised difficulties which do not exist in the case of a corporation, as the corporation has a legal existence independent of its members. ${ }^{2}$ One such is the ownership of property. ${ }^{3}$ Since in the case of an unincorporated association there is no legal entity separate from its members, a transfer of property cannot logically be made to the association under its name. ${ }^{4}$ Where an attempt to do so is made, if the disposition is not to fail, some means of explaining how the disposition takes effect has to be found. The problem can be avoided if proper consideration is given to the fact that the association has no persona capable of taking property. The usual means by which the problem is overcome is by transferring the property to trustees who hold it on behalf of the members of the association. That itself is not without its difficulties. ${ }^{5}$ The purpose of this article is to consider one aspect of the holding of property by unincorporated associations which seems hitherto to have attracted little attention in the UK courts, but which would seem to have the potential to cause difficulties on a frequent basis. The question is to what extent the law of adverse possession can be prayed in aid of unincorporated associations in order to make title to land where, for some reason or other, documentary title cannot be relied on.

\section{Dispositions To Unincorporated Associations}

To begin with, we may note that use of the name of an unincorporated association as the donee or grantee of property does not necessarily mean the

1 See Glennon, "Questioning the legal status of unincorporated associations" (2000) 51 NILQ 120.

2 The problems posed by unincorporated associations not having a legal persona separate from the members who make up the association are described in the Law Reform Advisory Committee for Northern Ireland's Disussion Paper No 9 Unincorporated Associations (2002).

3 See Warburton, "The holding of property by unincorporated associations" [1985] Conv 318; Ford, Unincorporated non-profit associations (1959).

4 So a lease cannot be made to an unincorporated association: Jarrott v Ackerley (1915) 113 LT 371; London Borough of Camden v Shortlife Community Housing (1993) 25 HLR 330. See also Henderson v Toronto General Trusts Corp [1928] 3 DLR 411; Canada Morning News Co v Thompson et al [1930] 3 DLR 833; Freeman v McManus [1958] VR 15.

5 If the members of the association are beneficiaries under a trust, they have an equitable interest in the assets held in trust for them. Disposition of an equitable interest must be in writing to comply with s6 of the Statute of Frauds (Ir) 1695 ( $\mathrm{cp}$ Law of Property Act 1925, s 53(1)(c)). How does the equitable interest of a member of the association pass on his resignation if the resignation is not made in writing? 
disposition is of no effect. There is no shortage of authority upholding testamentary gifts where the testator has made a disposition of property to an unincorporated association. If the gift is upheld, it is on the basis that the gift creates a trust for the purposes of the association, but that those purposes being charitable, the gift is valid; or alternatively, that the gift is a gift to the members of the association at the time the gift takes effect, ${ }^{6}$ so that the use of the association's name in effect dispenses with the need for the testator to include in his will a list of all such members. A refinement of this interpretation which seems best suited to meet the intention of the donor is that the gift is to the members, but subject to the contractual arrangements between them as association members. The position was explained by Cross $\mathrm{J}$ in Neville Estates Ltd $\mathrm{v}$ Madden: ${ }^{7}$

"The position as I understand it is as follows: Such a gift may take effect in one or other of three quite different ways. In the first place it may on its true construction be a gift to the members of the association at the relevant date as joint tenants so that any member can sever his share and claim it, whether or not he continues to be a member of the association. Secondly, it may be a gift to the existing members not as joint tenants, but subject to their respective contractual rights and liabilities toward one another as members of the association. In such a case a member cannot sever his share. It will accrue to the other members on his death or resignation, even though such members include persons who became members after the gift took effect. If this is the effect of the gift, it will not be open to objection on the score of perpetuity or uncertainty unless there is something in its terms or circumstances or in the rules of the association which preclude members at any given time from dividing the subject of the gift between them on the

6 See for example Cocks v Manners (1871) LR 12 Eq 574, where a gift to the Sisters of the Charity of St Paul at Selley Oak was upheld as a charitable gift, whereas a gift to the Dominican Convent at Carisbrook was upheld as a gift to the members of the Convent. Similarly a gift to an institution known as the Franciscan Friars of Clevedon was upheld as a gift to the members of the institution in In re Smith [1914] 1 Ch 937, Joyce J refusing to follow several Irish authorities in which similar gifts had been held void, on the ground that the cases were "far from satisfactory". A disposition to the committee of an association, rather than to the association itself, was upheld on the same basis in In re Clarke [1901] 2 Ch 110. If the disposition is to be upheld as a disposition to the members of the association at the time of the gift, it is essential that there is nothing in the disposition to prevent the members disposing of the property should they so wish, as the extract quoted in the text from the judgment in Neville Estates Ltd $\mathrm{v}$ Madden [1962] 1 Ch 832 shows. If the intention of the grantor was that the property should be held in trust for present and future members of the association, so that the present members could not dispose of the property, the disposition will fail for perpetuity. There is no failure however merely because the disposition is to trustees for the members of the association or to a committee of the members, so long as the members, trustees or committee can dispose of the property. See In re Clarke [1901] 2 Ch 110; In re Drummond [1914] 2 Ch 90. For a useful discussion, see Widdows, "Trusts in favour of associations and societies" (1977) 41 Conv (NS) 179.

7 [1962] 1 Ch 832. See also Re Cain [1950] VLR 382; Leahy v A-G for New South Wales [1959] AC 457; Re Goodson, deceased [1971] VR 801. 
footing that they are solely entitled to it in Equity. Thirdly, the terms or circumstances of the gift or the rules of the association may show that the property in question is not to be at the disposal of the members for the time being, but is to be held in trust for and applied for the purposes of the association as a quasi-corporate entity. In this case the gift will fail, unless the association is a charitable body."

Whether an inter vivos disposition of land in which the grantee is an unincorporated association would be held to be an assurance to the members of the association at the date of the grant is unclear. ${ }^{8}$ On the one hand the situation would seem to be similar to that in Wray v Wray, ${ }^{9}$ where an assurance of land in which the name of the grantee was the trading name of a partnership was held to be a transfer of the land to the members of the partnership at the time of the deed. ${ }^{10}$ Against that, in Jarrott $\mathrm{v}$ Ackerley ${ }^{11}$ Eve $\mathbf{J}$ rejected an argument that a lease to an unincorporated association was a lease to the members of the association at the date of the lease, holding the contention that the lease operated to render each member of the association liable on the lessee's covenants "wholly untenable". ${ }^{12}$ The cases are certainly distinguishable: in Wray v Wray the unincorporated body to which the grant was made was a trading partnership, whereas in Jarrott v Ackerley the lease had been made to a non-commercial association, a members' club. Again, in Wray v Wray the grant was a conveyance in fee simple, whereas in Jarrott $\mathrm{v}$ Ackerley the disposition was a lease imposing obligations on the lessee, and the potential liability of the members of the association under the covenants in the lease was a matter of some concern to Eve J. No such issue arose in Wray v Wray. A third way to distinguish the two cases is simply by reference to the number of members of the bodies in question. In Wray $v$

8 There are US authorities where courts have held assurances to unincorporated associations to be dispositions to the members of the association: see Ford, op cit p5, citing Byam v Bickford 140 Mass 31 (1885); Popovich v Yugoslav National Home Society Inc 106 Ind App 195 (1939); The Golden Rod 197 F 837 (1912). The possibility that a lease to an association might be construed as a lease to the members of the association is acknowledged in Henderson v Toronto General Trusts Corporation [1928] 3 DLR 411 and London Borough of Camden v Shortlife Community Housing (1993) 25 HLR 330.

9 [1905] 2 Ch 349.

10 See also Chartered Bank (Malaya) Trustee Ltd v Abu Bakar 1957-1 MLJ 40. In Alagappa Chettiar v Coliseum Café 1962-1 MLJ 111 a landlord sought possession of premises which had been let to a firm on a monthly tenancy 38 years earlier During that time there had been various changes in the partnership and the landlord argued that the estate vested in the original partners as tenants could not have passed to the present members of the partnership without proper instruments of transfer. Hill J considered that the argument might be sound had some evidence been adduced by the landlord to prove the case. In the absence of such, Hill $\mathbf{J}$ concluded that the landlord had acquiesced in and possibly approved changes in the partnership. In the US a different view has been taken: see Arthur v Weston 22 Mo 378 (1856), discussed in Ford, op cit, p 4.

11 (1915) 113 LT 371.

12 An argument that a lease could take effect as a disposition to the individuals who executed the counterpart, as trustees for the association, was rejected by Millett $\mathbf{J}$ with similar forthrightness in London Borough of Camden v Shortlife Community Housing (1993) 25 HLR 330. 
Wray there were four partners at the date of the grant: in Jarrott v Ackerley, to have held the lease valid as a lease to the members would have resulted in a tenancy held by the 2,000 members of the association. ${ }^{13}$ Notwithstanding these differences however, the similarity remains that in each case under the terms of the disposition land was assured to a grantee which had no existence in law independent of the members of the body in question.

The problems of holding that a disposition to an association is a grant to the members of the association are particularly acute where the subject-matter of the disposition is land. The problems are succinctly described by Faulkner $\mathbf{J}$ (dissenting) in the American case of Murphy v Traylor ${ }^{14}$ :

"In most jurisdictions which permit unincorporated associations to hold title to real property, the title is vested in the members thereof jointly. Under that theory in our State each and every member and his or her spouse would have to join in the execution of a deed or mortgage. But, what happen when a member leaves or dies? Do his or her heirs and next of kin have to be tracked down to get their signatures? And, suppose a member flatly refused to sign, could good and merchantable title be conveyed by the remaining members?"15

The same problems arise if the disposition is construed as a grant to the members subject to the contract between them. It is hard to see how the interest of any individual member can be divested otherwise than by instrument sufficient to assure that interest or by operation of law. The rules of the association may provide that on his resignation any interest he has in the assets of the association shall cease, but where there has been no assurance by an outgoing member of his interest in land owned by the members, it would seem that the only way that the title of the other members will be good is by adverse possession.

13 Cp London Borough of Camden v Shortlife Community Housing (1993) 25 HLR 330, where Millett J speaking of the argument that the lease could be construed as a grant to the members of the association said that "[s]uch a construction would lead to such manifest absurdity in the present case that no-one had the courage to advance it."

14292 Ala 78 (1974).

15 In the case the Supreme Court of Alabama held by a majority that a devise of realty to an unincorporated church was valid where the church was subsequently incorporated even though this took place after the death of the testator. Merrill J, giving the opinion of the majority of the court, held that title to the property passed under the will to the incorporated church regardless of whether it was held in trust by the trustees of the church, individual members of the unincorporated church, or the next of kin of the testator, and passed to the church when it was incorporated. Heflin J, concurring in the result, held that an unincorporated religious society did have the capacity to acquire property by devise, and would have overruled McLean v Church of God 254 Ala 134 (1950) in which the court had held that a gift of land by will to an unincorporated church failed, on the ground that as an unincorporated association the church could not hold title to land. The gift in that case could not be upheld as a charitable purpose trust as there was no evidence that the testator intended to create a trust of the property. There is however no discussion in the case of the possibility that the gift could have been construed as a gift to the members of the church individually. 
Equally, the question whether the members of the association can establish a title by long possession of the property will be relevant where there has been no disposition of property to the members of the association. Typically, the problem arises not because at some date in the past members of the association took possession of property unlawfully, but rather because at some date in the past a landowner allowed the association to enter on property and the association has been there ever since, without paper title. The difficulty arises commonly where the association in question is the congregation of a church and many years ago a founder member allowed his land to be used as the site for construction of the church building, but the same situation can exist in the case of any other association where land was provided for use of the association. Can the association rely on the Limitation Order to establish title to the land it possesses?

There appears to be no UK or Irish authority and only one Commonwealth authority on the matter. In the United States the question has arisen in a number of cases whether churches can rely on the Statute of Limitations in circumstances where a disposition of the land to trustees for the benefit of the church has failed. No clear picture emerges from the decisions. On the one hand there are cases which take the view that as the church, being an unincorporated association, has no persona, it cannot acquire title by adverse possession, it being said to be a requirement that for adverse possession to take place, there must be someone who can hold a legal estate in land. On the other hand, some decisions have allowed claims based on adverse possession, either on the basis that members of the association in their individual capacity, or alternatively, officers of the association either in their individual capacity or as such officers can run a title. There are problems however with such solutions: if the members of the association are now not the same as those who were in possession when title was extinguished against the landowner, how does title pass to the present members of the association? If the present members of the association have not each been in possession for 12 years, do past members have claims which are not barred? Can the trustees of the church be taken to have a title by the possession of the members of the association? The purpose of this article is to examine the various issues involved.

\section{Adverse Possession}

A detailed explanation of the nature of the doctrine of adverse possession is both outside the scope of this article and unnecessary for the present discussion. ${ }^{16}$ Nonetheless, a brief summary may be helpful as a starting point for an examination of whether an unincorporated association can rely on the doctrine to assert a title to land. The essence of the doctrine is that a person wishing to bring an action to recover possession of land must do so within the time limited for such actions under the Statute of Limitations. Article 21 of the Limitation (NI) Order 1989 provides that no action may be brought to recover land after the expiration of 12 years from the date on which the right of action accrued. ${ }^{17}$ Once the limitation period has expired

16 For a recent discussion of the doctrine see J A Pye (Oxford) Ltd v Graham [2002] 3 All ER 865.

17 Other time limits apply in certain cases. 
without the plaintiff having brought proceedings, the title of the plaintiff to the land is extinguished. ${ }^{18}$ The Order says nothing about the rights of the person in possession once the limitation period has expired, and the position is that the plaintiff's title having been extinguished, the person in possession has a better right to the land than anyone else. ${ }^{19}$ Difficult questions arise as to the precise nature of the rights of the person in possession, which need not be addressed here: ${ }^{20}$ for present purposes the question is whether an unincorporated association can rely on the provisions of the legislation to assert a title to land, whatever the precise nature of that title may be.

\section{Possession Originally Lawful}

One problem standing in the way of an association trying assert that the title of the paper owner has been extinguished is that if the association is in possession of the property by permission of the person in whom the land is vested, the possession of the association is not adverse for the purposes of the Limitation Order. Time does not run against a landowner who has permitted someone to have possession of the land. Were it otherwise, time would be running in favour of a tenant who was occupying under a lease granted by the landowner. Similarly, time does not run in favour of a licensee of the land against the owner who granted the licence. ${ }^{21}$ If therefore, in the case in question, the owner of the land granted permission to the association to use the land, time cannot be running in favour of the association.

All may not however be lost. If the arrangement was a tenancy at will or a bare licence, the arrangement will have come to an end on the death of the lessor $^{22}$ or the licensor ${ }^{23}$ so that possession by the association for twelve years from the death will mean that the association should be safe. Safety is not guaranteed however, as although the doctrine of implied licence has been abolished, ${ }^{24}$ there is nothing to prevent the courts from finding that in the circumstances of the case the person who succeeded to the paper title on the death of the original owner granted a new licence by implication from the facts. ${ }^{25}$ If such a finding is made, then the association's possession remains by permission and time will not be running. If the original landowner was a founder member of the association, and his successor is also a member of the

18 Limitation (NI) Order 1989, art 26.

19 Problems arise where the plaintiff was other than an owner in fee simple, e.g, a life tenant or a lessee. For the position as to reversioners and remaindermen, see Limitation (NI) Order 1989, art 22. For the position where the plaintiff is a lessee, see discussion in Fairweather v St Marylebone Property Co Ltd [1962] 2 All ER 288.

20 On this see Omotola, "The nature of interest acquired by adverse possession of land under the Limitation Act 1939" (1973) 37 Conv (NS) 85; Curwen, "The squatter's interest at common law" [2000] Conv 528.

21 See Hughes v Griffin [1969] 1 WLR 23; Powell v McFarlane (1977) 38 P \& CR 452; BP Properties Ltd v Buckler (1987) 55 P \& CR 337; Buckinghamshire CC v Moran [1989] 2 All ER 225; Onyx (UK) Ltd v Beard (14 March 1996, unrep).

22 James v Dean (1808) 11 Ves Jr 383.

23 Terunnanse v Terunnanse [1968] AC 1086.

${ }^{24}$ Limitation (NI) Order 1989, sch 1 para 8(5).

25 Ibid, para 8(6). See Jourdan, Adverse Possession (2003) para 35-16 ff and authorities there discussed; $c p$ Terunnanse v Terunnanse [1968] AC 1086. 
association, it may be that the court would have little difficulty in implying a new licence in the circumstances. Apart from that, if the successor is a member of the association, it is arguable that his own occupation of the land should prevent the joint occupation of the others being adverse possession by them, on the basis that where more than one person is in occupation, possession will be attributed to the person with lawful title. ${ }^{26}$ Such an argument did not however prevent the court in Churcher v Martin ${ }^{27}$ holding that trustees had established title by adverse possession even though one of the trustees was for most of the relevant period the paper owner of the land, Kekewich $\mathbf{J}$ saying that the joint possession of the trustees excluded that of any one of the joint possessors on his own behalf, and that the accident of the trustee's beneficial interest did not operate to defeat the title of the trustees which he intended to preserve.

\section{Ability To Hold Estate In Land}

Although Churcher v Martin may assist the association to overcome the difficulty where the paper owner is one of the members, there may be a more fundamental problem facing the association in trying to establish a title to land by adverse possession. Several of the cases in which claims have been advanced on behalf of unincorporated associations have failed on the ground that the lack of legal personality prevents the association being able to hold title, and accordingly prevents it from acquiring title by possession. In Heiskell $\mathrm{v}$ Trout ${ }^{28}$ land was conveyed to trustees for the purposes of building a house to be used by the minister of a church. The trusts were declared void by the court and the question arose whether the church could claim the land by adverse possession as against the various persons who had contributed the purchase money for the land, and who were entitled to the land under a resulting trust on failure of the declared trusts. The Supreme Court of Appeals of West Virginia held that no lapse of time, however long, could confer on the church any title, legal or equitable. The opinion of the court was delivered by Snyder J who said:

"In order to obtain a title by adverse possession or the lapse of time, the adverse claimant must be capable of a legal ownership of the property. Here the church, the alleged claimant, is incapable of holding the property under its claim, and therefore no possession or adverse claim by it could by the lapse of time or under the Statute of Limitations confer upon it any title or defeat the claims of the rightful owners."

Similarly, in The Afton band of Indians v A-G of Nova Scotia ${ }^{29}$ a claim to land was made by a band of Indians on the basis of adverse possession. It was not in doubt that the land in question had been occupied by the Band for very many years. Notwithstanding possession for more than the limitation period however, Jones $\mathbf{J}$ held that the claim of the Band could not succeed. The Band, being an association not having corporate status, could not acquire

26 See Jourdan, op cit, para 7-76 citing Littleton, s 701 and Jones v Chapman (1847) 2 Ex 803.

27 (1889) 42 Ch D 312.

$2831 \mathrm{~W}$ Va $810(1888)$.

29 (1978) 85 DLR (3d) 454. 
real property and consequently could not acquire a title to the land by possession. ${ }^{30}$

\section{A Person In Whose Favour Time Can Run}

In Stewart v White ${ }^{31}$ Sharpe J based his view that an unincorporated church could not acquire title by adverse possession on an analogy between adverse possession and prescription, and the inability of an unincorporated association to take a grant of property in its own name:

"By the theory of prescription and likewise of title by adverse possession, a grant is presumed from long acquiescence of the landowner in the exercise of asserted rights which are inconsistent with his own. As in the case of an actual deed there must be some person, either natural or artificial, who can take title. The church society collectively, being unincorporated, was without capacity to acquire or hold title."

The analogy between prescription and adverse possession is not valid in England and Wales, or in Northern Ireland. ${ }^{32}$ Prescription operates to confer a title to an easement or profit on the basis of a grant being presumed from long usage. The Limitation Order on the other hand operates simply to destroy the title of the paper owner. The Order does not transfer the title which is extinguished to the person whose possession of the land has brought that extinguishment about. ${ }^{33}$ Hence the inability of the grantee to hold a title to land does not logically prevent the Order operating to destroy the title of the paper owner. ${ }^{34}$ On the other hand, the requirement in the Order that there be a person in whose favour time can run for a cause of action to accrue ${ }^{35}$ may have the same result. As by definition an unincorporated association has no persona of its own, is it a person in whose favour time can run? ${ }^{36}$ If it is not, then the position would seem to be the same as that described in Heiskell v Trout, viz, that no lapse of time will defeat the title of the paper owner. In The Afton band of Indians v A-G of Nova Scotia ${ }^{37}$ one question was whether the Band, as an unincorporated association, was a "person" for

30 The court recognised however that members of the band as individuals could acquire title by possession: see discussion below, p 284 .

31 128 Ala 202 (1900).

32 See Buckinghamshire CC v Moran [1989] 2 All ER 225; Gray, Elements of Land Law ( $3^{\text {rd }}$ edn, 2001) p 250; Megarry \& Wade, The Law of Real Property $\left(6^{\text {th }} \mathrm{edn}\right.$, 2000) para 21-002.

33 Tichborne v Weir (1892) 67 LT 735.

${ }^{34} C p$ the situation in England where a minor is unable to hold a legal estate in land (Law of Property Act 1925, s 1(6)). Notwithstanding such incapacity, it appears that possession by a minor would operate to extinguish the title of the paper owner: see Powell v McFarlane (1977) 38 P \& CR 452; Jourdan, op cit, para 2040.

35 Limitation (NI) Order 1989, sch 1 para 8(1).

36 Cp The Reformed Church of Gallupville v Schoolcraft 65 NY 134 (1875) (Dwight $\mathrm{J}$ (diss)): "It is of the essence of adverse possession that the rightful owner should be kept out of possession by some person claiming title, and against whom he could bring an action to regain possession. . . Whom could the [paper owner] have sued in the present case? Not the unincorporated association, which for this reason cannot claim the benefit of the Statute of Limitations."

37 (1978) 85 DLR (3d) 454. 
the purposes of the Quieting Titles Act 1967 (Nova Scotia) which allowed a person claiming a property right in land to apply to court for a certificate. The court held that it was not, and the litigation had to proceed as a representative action by the members of the Band acting through the chief of the Band. On the other hand, and in contrast to the corresponding Canadian legislation applicable in the Afton band case, the Interpretation Act 1978 provides that unless a contrary intention appears, the word "person" where it appears in legislation includes a body of persons corporate or unincorporate. ${ }^{38}$ There seems to be nothing in the Limitation Order to indicate a contrary intention requiring "some person in whose favour the limitation period can run" to be read as excluding a body unincorporate. If an unincorporated association $i s$ a person in whose favour time can run under the Limitation Order, then after the limitation period has run the title of the paper owner will have been extinguished. That being so, what is the position then? In ordinary cases, the person whose possession has brought about the extinguishment of the title of the paper owner has a better claim to the land than anyone else; he has in other words a possessory title which he can transfer to a third party. That cannot be the position where an unincorporated association is concerned unless inclusion of an unincorporated association in the term "person" in the Limitation Order means also that the association has acquired a persona so as to enable it to acquire such a title. That would seem unlikely, as it begs the question, how could the association execute a transfer of its rights in the land to a third party? The result therefore would seem to be that if an unincorporated association is a person in whose favour time can run for the purpose of the Limitation Order, the title of the paper owner will be extinguished after the limitation period has expired, but the association, for want of a persona, is unable to assert whatever rights follow from the fact of possession.

\section{Where Trustees Exist}

If the fact that an unincorporated association lacks personality separate from its members prevents the association from asserting title by adverse possession, is the problem avoided where the association has trustees who have been appointed to hold property on its behalf? Where this is the case, the difficulties of there being no-one who can hold an estate in land, or in whose favour time can run, seem to be overcome. ${ }^{39}$ And if the trustees of the association can extinguish the title of the paper owner, will the position be that succession to the office of trusteeship means that the rights based on the Limitation Order pass to successors in office under the appointments provisions of the Trustee Act without conveyance? ${ }^{40}$ If this analysis is

38 Interpretation Act 1978, s 5 and sch 1, applicable to NI legislation by s 24 . For examples of an unincorporated association being a "person" in other contexts, see Davey v Shawcroft [1948] 1 All ER 827 and Frampton and anor (Trustees of Worthing RFC) v IRC [1987] 1 WLR 1057.

39 See The Reformed Church of Gallupville v Schoolcraft 65 NY 134 (1875).

40 See Trustee Act (NI) 1958, s39. Where land is acquired by bodies associated for religious purposes and is vested in trustees, the land vests also in the trustees' successors in office without conveyance: see Trustee Appointment Act 1850, s 1; also Trustee Appointment Act 1869 and Trustees Appointment Act 1890. This provision is unlikely however to be of assistance where land is acquired by 
possible, it gets over also the problem of the fragmentation of title which may follow from saying that it is the members of the association whose possession has barred the title of the paper owner, and accordingly it is they who have acquired title by possession. ${ }^{41}$

That trustees can acquire title by possession is established. Churcher v Martin $^{42}$ has already been noted. In Re Ingleton Charity ${ }^{43}$ the vicar and churchwardens of a parish were trustees of land which was used as a school. On closure of the school in 1929 the title of the trustees came to an end under the reverter provisions of the School Sites Act 1841. The trustees remained in possession of the land however and were held to have acquired title by possession after the limitation period had run. Two points are of interest for present purposes: first, the vicar and churchwardens had not been the same persons throughout, various changes in the offices having taken place; and secondly, the present vicar and churchwardens held the land on the trusts originally declared.

A number of American decisions exist in which courts have held that trustees of an unincorporated association can acquire title by adverse possession. In Bridges v Henson ${ }^{44}$ for example, a petition was brought by the trustees of an unincorporated church claiming title to land by adverse possession. The petitioners were not the original trustees who had taken possession of the land, but were successors in office, the petition stating the original trustees to have vacated office "by death, removal from the community or other causes" and the petitioners having become trustees by being "appointed, elected, and qualified according to the rules of discipline governing their organisation." The court held that the petitioners were entitled to judgment in an action to prevent the erection of a fence by the defendants on the land claimed by the petitioners. Likewise, in Burton $\mathrm{v}$ Smith $^{45}$ and Booth $\mathrm{v}$ Mason $^{46}$ trustees of a church were held entitled to land by adverse possession. In Salem Church of the United Brethren in Christ in Baltimore County v Numsen ${ }^{47}$ however the Court of Appeals of Maryland held that trustees of an unincorporated church could not acquire title by adverse possession to land where a grant of the land had failed to transfer paper title. While the court referred to various authorities including Heiskell v Trout and Stewart v White, noted earlier, its conclusion that "[t]he weight of authority therefore seems to hold that the trustees of this unincorporated religious association, never having been incorporated, do not acquire title by adverse possession" is unfortunately brief. $^{48}$

adverse possession, as the section refers to land acquired by conveyance, assignment or other assurance.

41 See discussion below, $\mathrm{p} 284$.

42 (1889) 42 Ch D 312.

43 [1956] Ch 585.

$44216 \mathrm{Ga} 423$ (1960).

45226 Ark 641 (1956).

46241 Ark 144 (1966).

$47191 \mathrm{Md} 43$ (1947). See also Jackson et al v Shaw 193 Md 578 (1949).

48 In reaching that conclusion the court distinguished two earlier decisions, Baltimore Life Insurance Co v Trustees of the Woodberry Avenue M. E. Church $148 \mathrm{Md} 129$ (1925) and Mayfield v Safe Deposit and Trust Company $150 \mathrm{Md} 157$ (1926), in both of which titles based on adverse possession by churches had been 
Salem Church v Numsen was considered in O.K.C. Corporation v Allen. ${ }^{49}$ There again trustees of an unincorporated church sought to establish title to land by adverse possession. The trial judge held that the trustees' predecessors in office had established possession and barred the title of the paper owner. This judgment was later reversed and judgment rendered that the trustees had no title to the land. From this the trustees appealed. By a majority, the Court of Civil Appeals of Texas held that the decision of the trial judge had been right. The majority view was given by Hutchinson J, who explained:

"It is true that an unincorporated association may not acquire title in its associational name, but it may acquire, hold and dispose of real property through elected trustees and their successors. Likewise, an unincorporated association which adversely occupies and possesses land in the required manner and for the proper length of time may acquire title by limitation by and though its trustees. The possession of the members for associational purposes is constructively the possession of the trustees who represent the association. . . Public policy also supports this view. The adverse possession statutes were primarily designed to repose land titles and to afford protection against the loose methods of conveyancing which obtained in the early days of our State. If individuals may take advantage of those statutes, there appears to be no good reason why other individuals, when joined together in an association and acting thought duly elected trustees, may not also." 50

It is thought that this represents the better view, and that accordingly, where an association has trustees who are appointed to hold property on behalf of the association, there is no reason why the title of the paper owner should not be extinguished after the limitation period has run. If the trustees have themselves been in possession of the land, the requirement in the Limitation Order that there be some person in whose favour time can run seems to be met. Even if the trustees have not themselves been in possession, the view in O.K.C. Corporation v Allen that possession by other members of the association is constructively ${ }^{51}$ the possession of the trustees seems satisfactory and would for example mean that where an association has a number of branches, but only one body of trustees for all the association's property, the possession of property by members of one branch will enable the trustees to claim title, even though the trustees have not personally been

upheld, on the ground that in each of the cases the church, although initially an unincorporated association, had subsequently been incorporated. It is arguable however that the decision in each case would have been the same even if the church had not been incorporated. What seems to have been important in each case is that, from the outset, possession taken by the trustees of the then unincorporated church was adverse to the claims of the persons entitled on the failure of the trusts.

49574 S W 2d 809 (1978).

50 Authorites referred to in judgment not reproduced.

51 "vicariously" may be a more accurate term in this context: see Jourdan, op cit, paras 7-05 and 7-80. 
in possession at that branch. Certainly in other contexts claimants have been able to rely on the occupation of others to assert possession by themselves in claims against the paper owner. ${ }^{52}$ So claimants have been able to assert adverse possession though the land has been occupied by their tenants. ${ }^{53}$ The position was recently reconsidered in Tang Tak Hong v Cheung Yat Fuk ${ }^{54}$ where the Court of Appeal in Hong Kong held that if a squatter lets land to a tenant the squatter remains in possession by the tenant through the receipt of rent. If the tenant fails to pay rent, the squatter can turn him out and the tenant cannot deny the landlord's title. That, the court considered, gives the squatter-landlord sufficient factual possession for the purposes of adverse possession. Similarly, claims based on adverse possession have been successful although the land has been in the occupation of a licensee of the claimant. In the last appeal to come to the Privy Council from Hong Kong, Sze To Chun Keung v Kung Kwok Wai David, ${ }^{55}$ the relevant facts were that in 1955 the defendant went into possession of land. In 1961 the Crown granted the defendant a permit to occupy the land, not realising at the time that it in 1905 it had made a grant of the land to the plaintiff's predecessor in title. When the grant came to light, the Crown revoked its permit. In an action for possession brought in 1990 the question for the court was the effect of the permit granted by the Crown. Delivering the opinion of the Privy Council Lord Hoffmann explained that for the purposes of limitation, from 1961 possession had to be regarded as being in the Crown, which possessed through its licensee, and this possession was adverse to the plaintiff, so that the plaintiff's title had been extinguished.

Whether the situation of a trustee claiming adverse possession by relying on the occupation of his beneficiary, and thus whether the trustees of an unincorporated association can rely on the occupation of the property by its members, is the same as those of claimants relying on the occupation of their tenants or licensees remains to be determined. There is authority that where a trustee lets his beneficiary into possession of the trust property the beneficiary is tenant at will of the trustee, ${ }^{56}$ which would seem to make the situation analogous to those considered above. Haigh $\mathrm{v}$ West ${ }^{57}$ also supports the view that trustees can rely on occupation of the land by the beneficiaries to assert adverse possession. There the churchwardens and overseers of a parish were successful in a claim to land based on adverse possession, where the land had been occupied by the vestry of the parish, which had granted tenancies of the land to the persons in occupation. Not only could the occupation of the land by the tenants be relied on by the vestry, the vestry's enjoyment of the land was attributable to the churchwardens and overseers of the parish, who were empowered by statute to hold land on behalf of the parish. ${ }^{58}$

52 See Jourdan, op cit, para 7-80 ff.

53 Smith v Stocks (1869) 17 WR 1135; Seddon v Smith (1877) 36 LT 168; Haigh v West [1893] 2 QB 19.

54 [2002] $1249 \mathrm{HKCU}$ 1. See also Tang Kwan Tai v Tang Koon Lam [2002] 1 HKCU 1329.

55 [1997] 1 WLR 1232.

56 Garrard v Tuck (1849) 8 CB 231; Melling v Leak (1855) 16 CB 652.

57 [1893] 2 QB 19.

58 The parish, being a fluctuating body of individuals, was unable to hold property. 


\section{Northern Ireland Legal Quarterly [Vol. 54, No. 3]}

\section{Title In The Members of The Association}

If however the views that an unincorporated association cannot establish title by adverse possession as it is incapable of holding title, or that it is not a person in whose favour time can run, and that the trustees of the association are in no better position, are correct, or the case is one where the association has no trustees for the purposes of holding property, it can still be argued that time runs against the paper owner as the individual members of the association are in possession. ${ }^{59}$ So much indeed was recognised in The Afton band of Indians v A-G of Nova Scotia and the other cases in which the association's lack of personality has prevented a claim based on adverse possession succeeding. The situation is analogous to the validation of a grant of property to an unincorporated association under the association's name by holding the grant to be a grant to the members of the association at the date of the grant. Where it is possible to identify who the members of the association were when adverse possession began, and so long as there have been no changes in the membership to date, the position is straightforward. The members of the association have been in possession for the length of time required to extinguish the title of the paper owner, and those members now have the title acquired by someone who has barred the title of the paper owner. In this situation membership of the association is of little relevance: the members have acquired title in their capacity as individuals, the association merely explaining their common interest. Problems arise however where the members of the association at the time adverse possession began are not the same as the present members of the association. In such a case the problem will be to show how the rights acquired after the limitation period has run have become vested in the present members of the association. $^{60}$ In some cases it may be that the present members of the association have been in possession for a sufficient time to bar the rights of former members, but this will not always be the case, and at the very least will present evidential difficulties in tracing the history of the membership. Where the facts show that rights based on adverse possession were acquired by a member and those rights have not themselves been extinguished by adverse possession of the current members, then by definition the present members cannot show they have title to the land.

59 There may however be difficulties if the pleadings do not show reliance on possession as individuals rather than as office holders of the association. In Stewart v White 128 Ala 202 (1900) the court found difficulties with attempts to base a claim brought by the deacons of a church on the possession of the claimants and other members of the church as individuals, the bill instituting the claim not showing that any particular person had acquired title, and not being framed on the theory of individual ownership. Again, in O.K.C. Corporation v Allen $574 \mathrm{~S} \mathrm{~W}$ 2d 809 (1978) Ray J (dissenting), while prepared to allow that the original trustees of the church could as individuals acquire title by adverse possession, held that the proceedings did not show that the claimants (the present trustees) had brought the suit claiming to be heirs or grantees of those individuals, and no attempt had been made to prove title in the present trustees as individuals.

60 This was one of the difficulties in The Afton band of Indians v A-G for Nova Scotia. Jones J was prepared to hold that title had vested by long possession in members of the Band. The problem was that there was no evidence to show who those members were, nor was it possible to conclude that title was vested in the present members of the Band. 
Gribble v Call $^{61}$ is a case where such difficulties did not prevent the court holding that the paper owner was prevented from recovering possession. The case involved land on which a memorial to the Confederacy had been erected. The land had been included in a conveyance made in 1907, by which the grantor purported to assure the land to the "General Dick Taylor Camp No. 1265, U.C.V., . . . and the R. E. Lee Chapter of the U.D.C." both of which were unincorporated associations. In the event the deed was of no effect, as the grantors did not have title to make the assurance. Following the deed however members of each association took possession of the land and built the memorial. In 1933 the surviving members of the Chapter of the UDC conveyed their interest in the land to the City of Jefferson, and in 1937 a similar deed was executed by various parties claiming to be heirs at law of the last surviving members of the Dick Taylor Camp. The defendant derived title from an assurance by the City. The plaintiff contended that as both the UDC and UCV were unincorporated associations, they were incapable of acquiring title by adverse possession. Notwithstanding the acceptance by the court that an unincorporated association cannot hold land, the court went on to hold that the paper owner could not succeed in his action to recover the land. The analysis of the situation was that following the deed of 1907 various individuals known as Confederate Veterans and others known as the Daughters of the Confederacy had gone into possession of the land. Leslie CJ said:

"We see no reason why the individuals of a group acting in concert with each other may not thus mature title to the real estate under the 10 years Statute of Limitations. Certainly the rightful owners of the lots, whoever they were, had a remedy against the individuals from the moment of appropriation by them back in 1907. Such owners did not sue them in trespass, eject them from the property, or otherwise vindicate their right of title and possession until long after the Statute of Limitations conferred an absolute title upon these individuals. It is the duty of the court to recognise such a title in them, the same as if it were a good record title."

Although referred to in Salem Church v Numsen as the strongest case to support the argument of the church there, the court did not discuss Gribble v Call further, saying merely that the weight of authority was against the church. The case was however referred to in The Afton band of Indians v A$G$ of Nova Scotia where Jones J refused to follow it because of what he described as the hiatus in the chain of the possessory title in the earlier case. It is however doubtful whether Gribble v Call posed any difficulty in the Afton band case. It is important to distinguish between the question whether the title of the paper owner has been extinguished after the limitation period, on the one hand, and the question whether the persons currently in possession have good title to the land, on the other. ${ }^{62}$ In The Afton band of Indians $\mathrm{v} A-G$ of Nova Scotia it was the latter question which was relevant, the present members of the Band seeking a certificate of title. Their failure to obtain the certificate was attributable not to the fact that the title of the

$61 \quad 123$ S W $2 d 711$ (1938).

62 See Sze To Chun Keung v Kung Kwok Wai David [1997] 1 WLR 1232; Tang Kwan Tai v Tang Koon Lam [2002] 1 HKCU 1329. 
paper owner was sound, but rather to the fact that it had not been shown that the title acquired as a result of adverse possession had passed to the present members of the Band. In contrast, in Gribble v Call, the question was whether the title of the paper owner had been extinguished. Whether the title of the defendant, as successor to the members of the associations who had taken possession, was sound, did not fall for consideration.

\section{Joint Tenants Or Tenants In Common?}

Assuming that members of the association took possession under circumstances sufficient to bar the title of the paper owner, what form of coownership exists between them? Are they joint tenants or tenants in common? The same question arises if the possessory title is in trustees rather than in the members of the association. Clearly a joint tenancy would make life simpler as time goes by: the interest of a member will accrue by survivorship to the others on that member's death. ${ }^{63}$ Basing his decision on a passage in Coke, ${ }^{64}$ Lord Hatherley LC held in Ward $\mathrm{v}$ Ward $^{65}$ that where two persons took unlawful possession of land they would hold as joint tenants, their title having arisen at the same time and they holding by the same right and having done nothing to sever their tenancy. Would the same principles apply in the case of possession by the individuals of an unincorporated association? In The Afton band of Indians v A-G of Nova Scotia Jones J thought that members of the Band who had taken possession of the land held as tenants in common, relying on a passage in Halsbury that joint possession results in a joint tenancy at law, but may give rise to a tenancy in common in equity. ${ }^{66}$ The question of how the members hold would seem to involve application of the presumptions applicable in ordinary cases of co-ownership of land. ${ }^{67}$

\section{A Different Approach?}

The issues discussed above clearly pose problems for an unincorporated association which has been in possession of land without title to it. The fact that the association has been in possession for a period long in excess of the limitation period may not, it would seem, mean that the title of the paper owner is extinguished. There may however be a different way to look at the problem. The courts have always been willing to find a title where possession has been enjoyed for a long period of time. As Fry LJ put it: ${ }^{68}$

"That possession is nine points of the law is a very common but very true saying, and it summarises a very considerable body of legal doctrine. One of the ways in which that doctrine

63 The right of survivorship in a joint tenancy will also avoid difficulties in passing a deceased member's interest to the other members of the association which would exist in a tenancy in common where the deceased member has not made a disposition of his interest in a manner complying with formalities for testamentary dispositions.

${ }^{64}$ Co Litt 181a.

65 (1871) LR 6 Ch 789.

6624 Halsbury's Laws of England ( $3^{\text {rd }}$ edn) p 260. See now 28 ibid ( $4^{\text {th }}$ edn (1979)) para 788.

67 See further Ford, op cit $\mathrm{p} 7$.

68 Halliday v Phillips (1889) 23 QBD 48. 
appears is this, that the Courts are under an obligation, which has been insisted upon over and over again, wherever they can, to clothe with legal right long continued and undisputed enjoyment; and in my judgment that obligation rests upon the Court although enjoyment may be shown to have had de facto an invalid or illegal or insufficient origin. I think where there has been long usage, long possession, or long enjoyment, even though there may be an original infirmity in the de facto commencement, the Court is bound to presume, if it can, that that illegal origin has been altered by something which has occurred in the course of time."

In A-G v Lord Hotham ${ }^{69}$ it is noted that very senior judges have said that they would presume anything in favour of a long enjoyment and uninterrupted possession. The question is whether a presumption could assist an unincorporated association which has been in possession of land for a long period of time, and if so, whether the difficulty that the association is unincorporated can be overcome.

Some assistance may come from Haigh $\mathrm{v}$ West. ${ }^{70}$ There the vestry of a parish had from 1774 let the pasturage of a road to tenants. There was no evidence as to who owned the road prior to 1774 , and no grant of the road was proved to exist. In an action by the lord of the manor following damage caused by one of the tenants of the vestry, the Court of Appeal held that the plaintiff could not succeed. Two grounds may be mentioned for the decision. First, the court held that the occupation of the land by the vestry of the parish was possession by the churchwardens and overseers of the parish, who had thereby acquired a title to the road by adverse possession. ${ }^{71}$ The other ground for the decision however was that it could be presumed that a grant of the land had been made to trustees on behalf of the parish. ${ }^{72}$ Charles $\mathrm{J}$, whose decision was confirmed by the Court of Appeal, said:

"it seems to me that I ought to presume, if it be possible, a person competent to make and a person competent to take a grant. Here it is clear there is a possible grantor. The lord of the manor at the time of the inclosure might have granted the right to a trustee for the benefit of the parish if he had thought fit. That indicates the possible grantee that I think I ought to presume - a trustee for the benefit of the parish. If the corporation of Saltash could take a several fishery clothed with a trust for an indeterminate body of inhabitants, why may not I assume that a possible grantor, such as the lord of the manor would be, could grant the land for an indeterminate body through the intervention, be it of the churchwardens or overseers or anybody who could hold for the benefit of the parish?"

69 (1823) T \& R 209.

70 [1893] 2 QB 19.

71 See discussion above, $\mathrm{p} 280$.

72 Cp Brocklebank v Thompson [1903] 2 Ch 344 where the court was prepared to presume a custom in favour of the inhabitants of a parish, as being an unincorporated body, they could not take title by grant. 
A similar exercise of the court's imagination would solve the difficulties facing an unincorporated association which has been in possession of land without title for a period sufficient to afford a presumption that possession had a lawful origin.

Even if the presumption of a grant to trustees for the benefit of the members of the association is not possible, there is always proprietary estoppel. ${ }^{73}$ Ironically, the difficulty for the association here may be proportional to the length of time the association has been in possession of the land. To succeed in a claim based on estoppel, the claimant must show some representation by the owner of the land, on which the claimant relied, that the claimant would acquire some right or interest in the land. ${ }^{74}$ The longer ago that representation was made, the more difficult it may be to prove. The inability to explain what took place when possession began is on the other hand the very basis upon which the court acts when presuming a grant or other means of clothing that possession with title.

\section{CONCLUSION}

The problems discussed above provide another illustration of the difficulty posed by the lack of separate personality of an unincorporated association. While the absence of UK and Commonwealth authority does provide a basis for arguing that the law must be working tolerably well in practice whatever the theoretical difficulties might be, it would seem from the existence of a significant body of US decisions that the problem is nonetheless a real one. It may be that the existence of trustees of an association may mean that the problem can be solved without the need for a more radical approach, but that is not beyond doubt, and in any event will not assist in cases where land is in the possession of an association whose rules do not provide for ownership of property through trustees. If the correct analysis is that the members of the association acquire as individuals a possessory title after the limitation period has run, the fragmentation of title which follows may well cause problems at a later date if the association decides to sell the property. A more attractive solution is required to the problem. The introduction of legislation to give unincorporated associations an existence independent of their members is one suggestion for reform which the Law Reform Advisory Committee has said may be an attractive and relatively simple solution to the problems which presently exist so far as unincorporated associations are concerned. ${ }^{75}$ Such a measure, based on US legislation, ${ }^{76}$ would allow an unincorporated association to acquire and hold land. It should also solve the problems with regard to adverse possession by such associations discussed in this article.

73 For proprietary estoppel, see Pawlowski, The Doctrine of Proprietary Estoppel (1996); Cooke, The Modern Law of Estoppel (2000); Spence, Protecting Reliance (1999).

${ }^{74}$ For the requirement in relation to the representation in detail, see Pawlowski, $o p$ cit $\mathrm{p} 21 \mathrm{ff}$.

75 See the Committee's Discussion Paper No 9, Unincorporated Associations, para 5.12 .

76 Uniform Unincorporated Non-profit Association Act, adopted in various States: see Law Reform Advisory Committee, op cit, ch 5. 